\title{
Knowledge of Pregnant Adolescents about Human Papillomavirus
}

\section{Conhecimento de adolescentes gestantes sobre o papilomavírus humano}

\author{
Erika Zambrano Tanaka ${ }^{1}$ Sílvia Souza Kamizaki ${ }^{1}$ Silvana Maria Quintana ${ }^{2}$ \\ Rodolfo de Carvalho Pacagnella ${ }^{3}$ Fernanda Garanhani Surita ${ }^{3}$
}

${ }^{1}$ School of Nursing, Universidade Estadual de Campinas, Campinas, SP, Brazil

2 Department of Gynecology and Obstetrics, School of Medicine, Universidade de São Paulo, Ribeirão Preto, SP, Brazil

${ }^{3}$ Department of Gynecology and Obstetrics, School of Medical

Sciences, Universidade Estadual de Campinas, Campinas, SP, Brazil

Rev Bras Ginecol Obstet 2019;41:291-297.

\author{
Address for correspondence Erika Zambrano Tanaka, School of \\ Nursing, Universidade Estadual de Campinas, Rua Tessália Vieira de \\ Camargo, 13083-887, 126, Campinas, SP, Brazil \\ (e-mail: eztanaka@unicamp.br).
}

\begin{abstract}
Keywords

- adolescent

- uterine cervical neoplasms

- human papillomavirus

Objective To evaluate the level of information possessed by pregnant adolescents regarding the human papillomavirus (HPV).

Methods Descriptive study developed in the adolescent prenatal outpatient clinic of a tertiary hospital from the state of São Paulo, Brazil. Data were collected between June and December 2017 following approval from the ethics and research committee (CAAE: $1.887 .892 / 2017)$. Pregnant adolescents, $\leq 18$ years old, who attended the abovementioned outpatient section, composed the sample. Those diagnosed with a psychiatric disorder and those with hearing or cognitive disabilities were excluded. After acceptance to participate in the present study, the pregnant adolescents signed an Informed Consent Form. Regarding the statistical analysis, the chi-squared test and the Fisher exact test were used.

Results Regarding the knowledge about HPV, 123 (80.92\%) of the participants had already heard about the subject; for 77 (50.66\%), their schools had been the source of the information; 101 (66.45\%) did not know how they could be infected by the virus. Age variation did not influence their knowledge on how to prevent themselves from HPV $(p=0.2562)$. The variable vaccine is associated with HPV prevention $(p<0.0001)$.

Conclusion The pregnant adolescents composing the sample have shown to have knowledge about HPV. However, they do not prevent themselves from it appropriately, given that little more than half of the sample was vaccinated, had not reported an understanding that the use of preservatives and vaccination are effective means of prevention, and did not correlate HPV with uterine cervical cancer.
\end{abstract}

(1)Erika Zambrano Tanaka's ORCID is https://orcid.org/0000-0001-

9913-2975.

received

May 25, 2018

accepted

April 4, 2019
DOI https://doi.org/

10.1055/s-0039-1688708.

ISSN 0100-7203.
Copyright $\odot 2019$ by Thieme Revinter

Publicações Ltda, Rio de Janeiro, Brazil
License terms

(c) (i) 


\section{Resumo}

\section{Palavras-chave \\ - adolescente \\ - câncer de colo de útero \\ - papillomavirus humano}

Objetivo Avaliar o nível de informação que as adolescentes gestantes possuem em relação ao papilomavírus humano (HPV).

Métodos Estudo descritivo desenvolvido no ambulatório pré-natal adolescente de um hospital terciário do estado de São Paulo, Brasil. Os dados foram coletados entre junho e dezembro de 2017, após a aprovação do comitê de ética e pesquisa (CAAE: 1.887.892/2017). A amostra foi composta por adolescentes gestantes com $\leq 18$ anos que frequentaram o ambulatório. Foram excluídas as com transtorno psiquiátrico diagnosticado e as portadoras de deficiência auditiva ou de cognição. Após aceitarem participar do presente estudo, as adolescentes grávidas assinaram o termo de assentimento e consentimento livre e esclarecido. Para as análises estatísticas, foram utilizados os testes de qui-quadrado e exato de Fisher.

Resultados Em relação ao conhecimento sobre o HPV, $123(80,92 \%)$ já tinham ouvido falar sobre o assunto; destas adolescentes, 77 (50,66\%) receberam as informações que tinham através de suas escolas, e 101 (66,45\%) pacientes não sabiam como poderiam contrair o vírus. A variação da idade das adolescentes entrevistadas não influenciou se estas sabiam ou não como se prevenir contra o HPV $(p=0,2562)$. A variável vacina está associada à prevenção contra o HPV $(p<0,0001)$.

Conclusão As gestantes avaliadas possuem conhecimento sobre o HPV, mas não fazem a prevenção adequada, visto que um pouco mais da metade se vacinaram, não relataram o preservativo e a vacina como métodos eficazes de prevenção, e não relacionaram o HPV com o câncer de colo de útero.

\section{Introduction}

The human papillomavirus (HPV) is a virus that belongs to the family Papovaviridae and is classified according to the potential to induce phenotypic changes to the cells as: low-risk group (DNA-BR) and high-risk group (DNA-AR) for oncogenesis. Both groups may cause abnormal cell growth, but only those rated as high-risk for oncogenesis cause carcinomas. ${ }^{1}$

Human papillomavirus infections are related to the beginning of the sexual activity in adolescents, presenting itself as a transitory phenomenon in $\sim 80 \%$ of the cases, receding within 1 year in $70 \%$ of the cases and in $90 \%$ of the cases up until 2 years; infection persists in between 10 and $20 \%$ of the cases. ${ }^{2}$ The HPV virus is considered to be the most common infectious agent regarding sexual transmission. The estimated number of women carrying the DNA of the HPV virus worldwide is 291 million, and $\sim 105$ million women worldwide will be infected by the HPV type 16 or type 18 at least once in their life. ${ }^{3}$

The HPV incidence is higher soon after the $1^{\text {st }}$ years of sexual activity when compared with other age ranges. It happens due to the systemic immaturity of the cervical epithelium in adolescents, associated with the nonusage of barrier methods. Studies show a prevalence rate $34.4 \%$ higher in adolescents when compared with other age ranges. Therefore, people $<20$ years old are considered more susceptible to the HPV. Even though these individuals are more likely to be infected, tracking exams are less frequent when compared with adult women. ${ }^{4}$ Other risk factors are: early beginning of sexual activity, multiparity, extended use of oral contraceptive, and immunosuppression, particularly the human immunodeficiency virus (HIV). ${ }^{5}$ Smoking is a risk behavior, given that the substances contained in cigarettes may significantly reduce the amount and the function of the Langherans cells, as well as of the antigen hosting cells, responsible for the activation of the local cell immunity against the HPV. ${ }^{6}$

Studies show a higher prevalence of the virus in expectant mothers (25.3\%) when compared with nonexpectant women (13\%). Therefore, pregnancy is considered a factor associated with the rise of HPV infection rates. Among the theories that justify this data, it is said that, during the gestational period, the body of the woman goes through hormonal changes and transitory immunocompetent depression. ${ }^{7}$ In addition, during this period, there are higher rates of viral replication, especially on the second half of the gestational period, increasing the risk of mother-to-child transmission, or vertical transmission (VT). ${ }^{2}$

Vertical transmission may occur during the intrauterine life via transplacental transmission, or on the moment of the passage of the fetus through the birth canal due to the direct contact with the infected genital tract. Vertical transmission of the HPV through breastfeeding is unlikely, given that this fluid does not provide viremia; however, a study has determined the HPV frequency in the placenta, in the colostrum and in the blood of the umbilical cord of parturient women and their neonates. The HPV was detected in $4 \%$ of the maternal side of the placenta, and in $3.3 \%$ of the fetal side; $2.2 \%$ on the umbilical cord blood, and $0.8 \%$ on the colostrum, with a VT rate of $50 \%$. The low oncogenic risk genotype tracked was the HPV-6 (60\%), and the high oncogenic risk was the HPV-16 and the HPV-18 (20\% each). ${ }^{8}$

High-risk HPV virus infection is an indispensable condition, although not sufficient, to the development of cervical cancer. 
Women who present with viral infection persistence due to failure of immunological mechanisms may have as consequence an alteration on the cervical epithelium and a malignant modification. Women that present with persistent highrisk HPV infection (HPVAR) constitute the real risk group for the development of cervical cancer. ${ }^{7}$ In Brazil, cervical neoplasia is considered a public health problem, because affected women are mostly economically active. According to the José Alencar Gomes da Silva National Cancer Institute (INCA, in the Portuguese acronym), 5,430 women died due to uterine cervical cancer (UCC) in 2013, and in 2018 there were 16,370 new UCC cases in Brazil, following the estimative, which represents a rise of $4.8 \%$ in comparison with 2014 , remaining as the $3^{\text {rd }}$ most prevalent cancer among Brazilian women, with an incidence estimated at 15,85 for every 100 thousand women. ${ }^{9}$

The way to effectively prevent HPV infection is vaccination, which faces big challenges when it comes to its implementation, especially due to the lack of knowledge of the population. Studies have shown that $60 \%$ of a group of fathers of interviewed adolescents did not know anything about the HPV; from the $40 \%$ that had any information regarding this matter, only $28.4 \%$ presented adequate statements. However, when well-informed, $94 \%$ were favorable to the vaccination of their sons, what reinforces the need for educative interventions, for the diffusion of information regarding HPV, and for preventive measures. ${ }^{10}$ In addition, the Brazilian Ministry of Health offers the cytopathological exam, whose main purpose is the early diagnosis of HPV in women between 25 and 59 years old. However, currently, Brazil does not reach its $80 \%$ goal for the target group, according to the World Health Organization (WHO). ${ }^{9}$ The Brazilian Unified Health System (SUS, in the Portuguese acronym) also offers barriertype contraceptive methods (masculine and feminine condoms), which are the only preventive methods for sexually transmitted infections. All of these strategies aim to prevent or early track HPV and then reduce future consequences related to the virus.

Hence, the present study aimed to evaluate the level of knowledge about HPV possessed by pregnant adolescents.

\section{Methods}

This is a quantitative study with a descriptive character that was developed on the adolescent prenatal outpatient (APNO) of the José Aristodemo Pinotti Women's Hospital, which is part of the hospital complex of the Universidade Estadual de Campinas, Campinas, state of São Paulo, Brazil. The hospital provides health care to women and has an interdisciplinary team and a prenatal department specialized in pregnancy during adolescence.

Data collection was performed on Tuesdays and Thursdays afternoons, from April to December 2017. The inclusion criteria were: (pregnant) adolescents $\leq 18$ years and 11 months old, who attended the outpatient sector. The exclusion criteria were: diagnosed psychiatric disorder or hearing or cognitive disabilities that might hinder interaction.

The instrument used was an adaptation of the one developed at the Department of Infectious Diseases (SEMIGO) of the Department of Gynecology and Obstetrics of the Hospital das Clínicas of the Medical School of Ribeirão Preto, University of São Paulo. The adaptation has 36 questions, starting with questions regarding identification, socioeconomic and gynecological status, and finally about the knowledge about HPV and vaccination. The survey was performed with simple language, easily understandable by the participants. After filling out the form, the participants received directions about HPV and uterine cervical cancer prevention, aiming to enlighten possible doubts that might arise from filling out the questionnaire.

Regarding the statistical analysis, the nonparametric MannWhitney test was performed for: comparisons involving one qualitative variable with two categories and one quantitative variable. To analyze the associations between qualitative variables, the chi-squared test was applied. When the postulates of the chi-squared test were not met, the Fisher exact test was applied. ${ }^{11}$ For all of the analyses, the statistical software SAS version 9.4 (SAS Institute Inc., Cary, NC, USA) was used; the assumed level of significance for the statistical tests was $5 \%$.

Every legal and ethical aspects were respected. The project was approved under the CAAE number 62791316.9.0000.5404, 1.887 .892 on $10 / 01 / 2017$, thus respecting the resolution 466 / 2012 from the National Health Council and the Declaration of Helsinki (III Declaration of Helsinki, 2000).

The informed consent forms were signed and obtained before the admission of the pregnant women to the present study, being guaranteed the confidentiality regarding the source of the information and the right to leave the study at any moment without any loss regarding the treatments at the institution.

The methodological quality of the present study was evaluated according to the strengthening the reporting of observational studies in epidemiology (STROBE) statement, which is based on the STROBE 2007 checklist.

\section{Results}

The sample comprised 152 adolescents; there was no refusal to the participation, and the sociodemographic and obstetrical characteristics are shown and described on - Table 1.

The average age was 16.08 years old (standard deviation [SD] $=1.56$ ). In terms of skin color, $84.21 \%$ self-declared themselves as non-white. Regarding the marital status, $58.55 \%$ declared to live with their partners, $86.84 \%$ declared themselves as in a stable relationship, and $33.4 \%$ declared to be in the current relationship for no longer than 1 year. Regarding education, $15.79 \%$ had high school education, $21.05 \%$ were students, and one self-declared as not having any education. Out of the total sample, $84.87 \%$ had appropriate schooling, according to their age. Regarding the usage of psychoactive substances, $33(21.71 \%)$ had made use of any substance at least once; out of these, 23 (15.13\%) used marijuana, and 6 (3.95\%) used cocaine. Regarding smoking, 20 (13.16\%) had never been smokers, and 9 (5.92\%) were former smokers due to the pregnancy. A total of 57 (37.50\%) participants made use of alcohol.

Regarding the gynecological data, the average age for the $1^{\text {st }}$ sexual relation was 14.16 years old $(S D=1.34)$, and 
Table 1 Sociodemographic characteristics of the sample $(n=152)$

\begin{tabular}{|l|l|l|}
\hline Variable & $n$ & $\%$ \\
\hline Skin color* & & \\
\hline White & 24 & 15.79 \\
\hline Black & 52 & 34.21 \\
\hline Brown & 76 & 50.00 \\
\hline Living with the partner & & \\
\hline Yes & 89 & 58.55 \\
\hline Stable relationship & & \\
\hline Yes & 132 & 86.84 \\
\hline Appropriate age ${ }^{* *}$ & & \\
\hline Yes & 126 & 84.87 \\
\hline
\end{tabular}

*IBGE (Brazilian Institute of Geography and Statistics).

${ }^{* *}$ Appropriate age $=$ Adolescent with schooling in accordance with their age.

the average age for the first pregnancy was 16.01 years old $(\mathrm{SD}=1.62)$. Regarding the gestational record, $141(94.76 \%)$ were primigravida, 9 (5.92\%) were secundigravida, and 8 (5.26\%) had had one abortion. Regarding the marital status, 146 (97.33\%) had only had sexual relations with 1 partner during the previous 12 months. Regarding sexual health, $13(8.55 \%)$ declared that they had already been diagnosed with a sexually transmitted infection (STI); out of these, 1 knew what the diagnostic was: gonorrhea. Regarding knowledge about HPV, 123 (80.92\%) had already heard about it; 77 (50.66\%) had obtained the information they had at school. In this sample, 101 (66.45\%) patients who did not know how they could contract the virus were found (-Table 2).

The comparison between the age of the interviewed women and their knowledge about HPV prevention was not statistically significant, which means that the age variation did not influence their knowledge about how to prevent themselves from HPV $(p=0.2562)$. - Table 3 is a comparison using the exact Fisher test and the chi-squared test. The relation between HPV prevention and the variables race, schooling, preservative usage, and vaccination was analyzed. The variables race and schooling did not present a statistically significant relation. The variables vaccine and preservative $(p<0.0001)$ are statistically associated with HPV prevention according to the interviewed group (95.83\%).

\section{Discussion}

A total of 137 thousand cases of HPV infection are diagnosed every year in Brazil; $44.7 \%$ of the infected individuals are adolescents and socioeconomically disadvantaged women, and the present study found similar characteristics. Most infected women began their sexual life before 18 years old and there was no significant difference regarding how many sexual partners they had; there was a predominance of
Table 2 Approached matters regarding knowledge about HPV $(n=152)$

\begin{tabular}{|c|c|c|c|}
\hline \multicolumn{2}{|l|}{ Variable on HPV } & \multirow{2}{*}{$\begin{array}{ll}n \\
123\end{array}$} & \multirow{2}{*}{$\begin{array}{l}\% \\
80.92\end{array}$} \\
\hline "Ever heard about HPV?" & Yes & & \\
\hline \multirow{5}{*}{$\begin{array}{l}\text { "Where did you } \\
\text { hear about HPV?" }\end{array}$} & School & 77 & 50.66 \\
\hline & Home & 06 & 3.95 \\
\hline & Health center & 34 & 22.37 \\
\hline & Social network & 18 & 11.84 \\
\hline & Friends & 11 & 7.24 \\
\hline $\begin{array}{l}\text { "Does HPV have any } \\
\text { relationship with uterine } \\
\text { cervical cancer?" }\end{array}$ & No & 99 & 65.13 \\
\hline \multirow[t]{3}{*}{$\begin{array}{l}\text { "Did you how the } \\
\text { HPV was transmitted?" }\end{array}$} & $\begin{array}{l}\text { No } \\
\text { Sexual relation }\end{array}$ & $\begin{array}{l}101 \\
48\end{array}$ & $\begin{array}{l}66.45 \\
31.58\end{array}$ \\
\hline & Saliva & 04 & 2.63 \\
\hline & Blood & 06 & 3.95 \\
\hline \multirow{2}{*}{$\begin{array}{l}\text { "How do you } \\
\text { prevent from HPV?" }\end{array}$} & Preservative* & 49 & 32.24 \\
\hline & Vaccination & 24 & 15.79 \\
\hline $\begin{array}{l}\text { "Do you know what is the } \\
\text { function of oncological } \\
\text { cytology?" }\end{array}$ & No & 97 & 63.82 \\
\hline $\begin{array}{l}\text { "Did you get the } \\
\text { HPV vaccine?" }\end{array}$ & No & 85 & 55.92 \\
\hline
\end{tabular}

*Preservative usage: only masculine was mentioned.

Table 3 Relation between variables race, schooling, preservative usage, and vaccination on HPV prevention $(n=152)$

\begin{tabular}{|l|l|l|l|l|l|}
\hline \multirow{2}{*}{ Variable } & \multicolumn{3}{l}{ Knew how to prevent from } & \multirow{2}{*}{ p-value* } \\
\cline { 2 - 5 } & HPV & \multicolumn{2}{l}{ Yes } & \multirow{2}{*}{} \\
\cline { 2 - 5 } & $n$ & $\%$ & $n$ & $\%$ & \\
\hline Race & & & & & 0.6169 \\
\hline White & 14 & 58.33 & 10 & 41.67 & \\
\hline Black & 36 & 69.23 & 16 & 30.77 & \\
\hline Brown & 48 & 63.16 & 28 & 36.84 & \\
\hline Schooling & & & & & 0.1903 \\
\hline $\begin{array}{l}\text { No studies to } \\
\text { incomplete } \\
\text { high school }\end{array}$ & 40 & 58.82 & 28 & 41.18 & \\
\hline $\begin{array}{l}\text { Complete high } \\
\text { school to } \\
\text { incomplete } \\
\text { higher education }\end{array}$ & 58 & 69.05 & 26 & 30.95 & \\
\hline Appropriate age & & & & & \\
\hline No & 12 & 52.17 & 11 & 47.83 & \\
\hline Yes & 86 & 66.67 & 43 & 33.33 & \\
\hline Preservative & & & & & $<0.0001$ \\
\hline No & 98 & 95.15 & 5 & 4.85 & \\
\hline Yes & 0 & 0.00 & 49 & 100.00 & \\
\hline Vaccine & & & & & $<0.0001$ \\
\hline No & 97 & 75.78 & 31 & 24.22 & \\
\hline Yes & 4.17 & 23 & 95.83 & \\
\hline
\end{tabular}

${ }^{*} p$-value obtained from the chi-squared test. 
women in stable relationships. ${ }^{12}$ These findings draw the attention because of a casuistry of similar framework.

Regarding the HPV, most if the interviewed individuals had some information; however, predominantly, they showed no knowledge about transmission, prevention, symptomatology, and about the consequences of it. Such thing was already shown in the literature: in general, people, including those in the age group of higher risk, have inappropriate knowledge about HPV. ${ }^{13}$ We need educational interventions that focus not only on the transmission of information, but also on the exchange of knowledge according to the capacity of the different social groups involved, making such intervention effective.

In 2014, the Brazilian Ministry of Health ${ }^{14}$ began a big campaign for HPV vaccination in Brazil, called the National Program for Immunization (NPI), given that vaccination is the only method with scientific evidence for HPV prevention. However, this program evoked a big challenge in the health education sphere. Its results indicated that most adolescents obtained information about HPV through the media, their schools or health professionals; however, they had no appropriate information about the virus. Here, the relevance of the different sources of information and its potential to contribute to the health of the people can be discussed, given that health promotion lies among the fundamental aspects of the SUS. $^{14}$

The vaccination plan adopted on the first moment of the campaign consisted of vaccination in 3 doses: the $1^{\text {st }}$ dose, the $2^{\text {nd }}$ dose, 2 months after the $1^{\text {st }}$, and the $3^{\text {rd }}$ dose, 6 months after the 1 st. Changes were implemented in the 2016 vaccination calendar, and the $2^{\text {nd }}$ dose was no longer necessary, given that studies showed that the antibody response was not different for girls who had received the $1^{\text {st }}$, the $2^{\text {nd }}$, and the $3^{\text {rd }}$ doses when compared with those who had received only the $1^{\text {st }}$ and the last doses, so the $2^{\text {nd }}$ phase began focusing on the age (between 9 and 13 years old) and on the number of doses (the $1^{\text {st }}$ and the last, 6 months later). The vaccine is safe, effective, and the main way to prevent the 4 types of $\operatorname{HPV}(6,11,16,18)$, being the viruses type 16 and type 18 present in 70\% of the UCC cases, and types 6 and 11 present in $90 \%$ of the cases of genital warts. This year, the 2018 campaign wants to elicit the importance of the carers in what comes to the future and education of the girls. The strategy to the adherence to the campaign remains both on the health centers and on the schools. It is important to emphasize that the 3 doses scheme ( 0,2 , and 6 months) was maintained to remains for all girls and women 9 to 26 years old with HIV. ${ }^{15}$

The objective of a study was to carry out an intervention on the HPV vaccination coverage. Trained educators and health professionals worked together and began a campaign with a multidisciplinary team, and as a result, the efficiency of the vaccination coverage grew when compared with the previous year, showing that an intervention that embraces many fields is more effective and reaches a greater number of people. This aspect can also be verified by taking into consideration the majority that declared that they had received information about HPV at school, not from health professionals. With this in mind, the urgency for strategies of action regarding this risk group can be discussed. ${ }^{16}$

From that, an important flaw in the vaccination process can also be pointed, which can be associated with many causes, from the health education methodology to the lack of knowledge of the health professionals: $72.6 \%$ of the community agents from a basic health unity had no knowledge about HPV, ${ }^{17}$ and this deficit of knowledge about the matter makes them inapt to fulfil their role on promoting health.

A study with Brazilian university students showed that 77\% heard about HPV, 65\% from the media, 38\% from television, $28 \%$ from health professionals and $31 \%$ from the vaccine. $^{18}$

This study presents the strategies used by the nurses in a health center to inform women regarding HPV. They make use of rounds of conversations and educative groups to encourage active search and health education. The study brings the importance to seize the times when the women go to the health service, including the times when the team is discussing other types of intervention, to enhance the education regarding health. ${ }^{19}$

Only $55.92 \%$ of the adolescents referred themselves as vaccinated from HPV; $46 \%$ stated that they had received 2 doses of the vaccine, but the presentation of the vaccination card was not requested in the moment of the data collection, so the information could not be checked. It can be observed that younger adolescents, who possessed no further education than incomplete high school, had greater knowledge regarding HPV prevention, showing that the vaccination and prevention campaigns at schools are of utmost importance.

The Brazilian Ministry of Health indicates the school as a relevant scenery for the development of a health culture and for the establishment of healthy environments. The interaction between the community and the school motivates the involvement in collective discussions aiming to find solutions to health promotion and prevention praxis.

The gaps of knowledge about HPV infection and its possible consequences may diminish the effectiveness of the vaccination programs. Therefore, it is essential to promote campaigns and educational interventions about the risks of transmission, and about the ways to protect and the consequences of HPV-related diseases, aiming to diminish the individual morbidity and the costs for the health system. ${ }^{20}$ This must be done via multidisciplinary teamwork, for instance, creating a cross-reference relation between schools and health centers, developing public health policies for the education and counselling of the population, as well as an identification and the reinforcement of strategies that promote growth when it comes to the adherence to the vaccination and early tracking, as well as promoting the empowerment of women regarding HPV and health care.

A study with fathers of girls found that $24 \%$ of them recognized HPV as the main risk factor for cervix uteri neoplasia, and that $79 \%$ knew about the existence of the vaccine. The level of confidence in the vaccine shows that the fathers were not afraid that their daughters could have their behavior 
influenced, regarding an early onset of sexual activity for the vaccinated girls, but $74.7 \%$ of parents of girls in the $9-13$ age group believe they are responsible for deciding whether or not to take the vaccine. ${ }^{21}$

Regarding the lack of knowledge about the oncologic cytology by the adolescents (36.18\%), the recommendation from the Health Ministry for the implementation of uterine cervical cancer tracking (once every three years) in women $\geq$ 25 years old who have active sexual life can be justified. Thus, the same lack of knowledge can also be expected from young people $<18$ years old; however, interventions aiming prevention must be developed, given that all of these girls already have active sexual life and neglect the use of condoms.

These findings lead to considerations about the impact of sexual education on these adolescents and about how to make it more effective. We believe that the implementation of educative activities in schools, both for students and parents, with trained health professionals with consistent knowledge on sexual education and sexually transmitted infections, can be viable and efficient regarding this framework of lack of knowledge about HPV.

Not asking for the vaccination card of the adolescent can be pointed as a limitation of the present study, because, frequently, they did not bring it with them when they returned for the next appointment. It is known that the answer about whether they had been vaccinated against HPV can be biased, given that it is possible that they might have been even though they were unable to name the vaccine.

\section{Conclusion}

Pregnant women accompanied in the prenatal outpatient sector have information about HPV, but do not know how to appropriately prevent it, since little more than half of the adolescents were vaccinated, did not report condoms and vaccine as effective means for prevention, and did not link HPV to UCC. The knowledge about HPV does not block the infection by itself; nevertheless, it can avoid the emergence of cancer by the search for preventive measures and for an early diagnosis, such as periodical tracking. These results are expected to provide insights into the future development of a guideline primer on HPV and on the prevention of cervical cancer, thus planning educational activities for adolescent girls of sexually active age. These findings lead us to reflect on the impact of the sexual education of these adolescents and on ways of making it more effective. We believe that conducting educational activities in schools, with trained health professionals who have knowledge about sex education and STIs, is an efficient and feasible intervention for the improvement of this deficit in the knowledge of the population about HPV.

\section{Contributors}

Tanaka E. Z., Kamizaki S. S., Quintana S. M., Pacagnella R. C. and Surita F. G. contributed with the project and data interpretation, the writing of the article, the critical review of the intellectual content, and with the final approval of the version to be published.
Conflicts of Interests

The authors have no conflicts of interests to declare.

\section{Acknowledgments}

The present study was supported and financed by the Fund for Teaching, Research and Extension (FAEPEX, in the Portuguese acronym) of the Universidade Estadual de Campinas ( $\mathrm{N}^{\circ}$ 519.292).

\section{References}

1 Freitas WR, Fedrizzi EM, Aguiar FG. Knowledge among college students and employees of local health units about human papillomavirus and cervical cancer and its implications for public health strategies and vaccination. DST J Bras Doenças Sex Transm. 2015;27:40-44. Doi: 10.5533/DST-2177-8264-2015271-208

2 Salcedo MMBP, Damin AP, Agnes G, et al. Prevalence of human papillomavirus infection in pregnant versus non-pregnant women in Brazil. Arch Gynecol Obstet 2015;292(06):1273-1278. Doi: 10.1007/s00404-015-3752-8

3 Silva EP, Vietta GG, Golfetto L, et al. Frequency and genotyping of human papillomavirus in women submitted to citology. DST J Bras Doenças Sex Transm. 2015;27:22-28. Doi: 10.5533/DST2177-8264-2015271-205

4 Medeiros LR, Ethur ABM, Hilgert JB, et al. Vertical transmission of the human papillomavirus: a systematic quantitative review. Cad Saude Publica 2005;21(04):1006-1015. Doi: 10.1590/S0102$311 \times 2005000400003$

5 Pirtea L, Grigoraş D, Matusz P, et al. Human papilloma virus persistence after cone excision in women with cervical high grade squamous intraepithelial lesion: a prospective study. Can J Infect Dis Med Microbiol 2016;2016:3076380. Doi: 10.1155/2016/3076380

6 Burchell AN, Winer RL, de Sanjosé S, Franco EL. Chapter 6: Epidemiology and transmission dynamics of genital HPV infection. Vaccine 2006;24(Suppl 3):S3, 52-61. Doi: 10.1016/j.vaccine.2006.05.031

7 Etchebehere RM, Almeida ECS, Côbo EC, Duque ACR. Murta EFC, Adad SJ. Comparison of classical and secondary cytologic criteria for diagnosing human papillomavirus. Rev Bras Ginecol Obstet 2016;38:41-46. Doi: 10.1055/s-0035-1570105

8 Teixeira LO, Amaral SC, Finger-Jardim F, et al. [Frequency of Human Papillomavirus in the placenta, in the colostrum and in the umbilical cord blood]. Rev Bras Ginecol Obstet 2015;37(05): 203-207. Doi: 10.1590/SO100-720320150005293

9 Ministério da Saúde. Secretaria de Atenção à Saúde. Departamento de Atenção Básica. Controle dos Cânceres do Colo do Útero e da Mama. 2nd ed. Brasília, DF: Ministério da Saúde; 2013

10 Pizzol D, Putoto G, Chhaganlal KD. Human papillomavirus (HPV) infection: a Mozambique overview. Virusdisease 2016;27(02): 116-122. Doi: $10.1007 / \mathrm{s} 13337-016-0319-7$

11 Mehta CR, Patel NR. A network algorithm for performing Fisher's exact test in $\mathrm{r}$ x c contingency tables. J Am Stat Assoc 1983; 78:427-434. Doi: 10.1080/01621459.1983.10477989

12 Ceccato Junior Benito Pio Vitorio, Guimarães Mark Drew Crosland, Lopes Ana Paula Ceccato, Nascimento Lorena Fiorini, Novaes Luísa Magalhães, Castillo Dora Méndez del et al . Incidence of Cervical Human Papillomavirus and Cervical Intraepithelial Neoplasia in Women with Positive and Negative HIV Status. Rev. Bras. Ginecol. Obstet. [Internet]. 2016 May [cited 2019 Apr 24]; 38(5): 231-238. Available from: http://www.scielo.br/scielo.php?script=sci_arttext\&pid=S0100-72032016000500231\&lng=en. http://dx.doi.org/ 10.1055/s-0036-1583294.

13 Osis MJD, Duarte GA, Sousa MH. [SUS users' knowledge of and attitude to HPV virus and vaccines available in Brazil]. Rev Saude Publica 2014; 48(01):123-133. Doi: 10.1590/S0034-8910.2014048005026

14 Ministério da Saúde. Secretaria de Vigilância em Saúde. Departamento de Vigilância das Doenças Transmissíveis. Nota Informativa N 149: Informa as Mudanças no Calendário Nacional de Vacinação 
para o ano de 2016. Brasília, DFMinistério da Saúde2015https:// www.cvpvacinas.com.br/pdf/nota_informativa_149.pdf. Acessado Janeiro 12, 2018.

15 Pereira RGV, Machado VMP, Mutran TJ, Santos LS, Machado JLM. Avaliando o conhecimento sobre o papilomavírus humano (HPV) e sua vacina. States Health 2015;6:135-143

16 McLean HQ, VanWormer JJ, Chow BDW, et al. Improving human papillomavirus vaccine use in an integrated health system: impact of a provider and staff intervention. J Adolesc Health 2017;61(02):252-258. Doi: 10.1016/j.jadohealth.2017.02.019

17 Manoel AL, Rodrigues AB, Piva EZ, Warpechowski TP, SchuelterTrevisol F. Evaluation of knowledge about the Human Papilloma Virus (HPV) and its vaccination among Community Health Agents in the municipality of Tubarão, Santa Catarina, Brazil, in 2014. Epidemiol Serv Saude 2017;26(02):399-404. Doi: 10.5123/s167949742017000200017
18 Burlamaqui JCF, Cassanti AC, Borim GB, Damrose E, Villa LL, Silva L. Human Papillomavirus and students in Brazil: an assessment of knowledge of a common infection - preliminary report. Rev Bras Otorrinolaringol (Engl Ed) 2017;83(02):120-125. Doi: 10.1016/j. bjorl.2016.02.006

19 Souza SV, Ponte KMA, Araújo DG. Prevenção do HPV nas mulheres: estratégia adotada por enfermeiros na atenção primária. Sanare. 2015;14:46-51

20 Tsuchiya CT, Lawrence T, Klen MS, Fernandes RA, Alves MR. O câncer de colo do útero no Brasil: uma retrospectiva sobre as políticas públicas voltadas à saúde da mulher. J Bras Econ Saúde. 2017;9:137-147. Doi: 10.21115/JBES.v9.n1.p137-47

21 Chehuen Neto JA, Braga NAC, Campos JD, et al. Atitudes dos pais diante da vacinação contra HPV na prevenção do câncer de colo do útero. Cad Saude Colet 2016;24:248-251. Doi: 10.1590/1414$462 \times 201600020275$ 